Reviewed Article - Clinic, the University and Society

\title{
Gathering the Excluded Voice: The TXT Inside/TXT Outside Project
}

\author{
Richard Owen \\ University of Essex, UK \\ rowenb@essex.ac.uk
}

\section{INTRODUCTION}

The TXT Inside/TXT Outside Project was an interdisciplinary community legal education project. ${ }^{1}$ It was a collaboration between a legal academic, computing and social scientists, and a conceptual artist. The project involved young offenders held under secure conditions in a Young Offender Institution using text art to reflect on their experiences of law, life and the legal system.

The aim of the project was to engage the young offenders and the general public in a discussion about the treatment of young offenders using narrative techniques. The voices of young people held in custody (Inside) were 'gathered' and 'released', to be seen, heard and responded to by the public at large (Outside). The focal point of the

1 I would like to thank Helen Power, Reader in Law, University of South Wales for commenting on a draft of this article. Any mistakes are, of course, my own.

The project was funded by Beacon for Wales a community engagement fund for universities in Wales funded by the Higher Education Councils, Research Councils UK and Wellcome Trust. It was formed from a partnership between Cardiff University, the University of Glamorgan, Amgueddfa Cymru-National Museum Wales, Techniquest, and BBC Cymru Wales. The project team consisted of members of staff from Artstation (Glenn Davidson); the School of Social Sciences (Michael Shepherd) and School of Computer Science \& Infomatics, (Ian Grinstead) Cardiff University; and University of Glamorgan Law School (Richard Owen). The University of Glamorgan ceased to exist in April 2013 when it merged with University of Wales, Newport to form the University of South Wales. 
action was a 'stage event' in the centre of Cardiff, where the text messages of a small group of young people in custody were displayed on a large screen, with the public being invited to respond by texting their own messages. A documentary film from the event, which included the projections and interviews with the public, was subsequently shown to and discussed with participating young people in custody. ${ }^{2}$

\section{THEORETICAL BACKGROUND}

\section{Community Legal Education}

There are four broad goals for community legal education as distilled from Gandhi, Freire, hooks, and Lopez:

(i) empowerment with legal knowledge to enable the community to advocate for its own self-interests;

(ii) collaborating with the community to facilitate community legal education;

(iii) teaching and learning in context;

(iv) teaching multi-dimensional lawyering skills and instilling a commitment to social justice. ${ }^{3}$

The aim was to create a discussion about the experiences of young offenders with members of the public to provide a space so that they could reflect on their views.

An abridged version of the film can be viewed at <http://www.artstation.org.uk/TXToutside/video.htm> accessed 25 January 2014.

MM Barry and others, 'Teaching Social Justice Lawyering: Systematically including Community Legal Education in Law School Clinics' [2012] 18 Clinical Law Review 401, 424 
This was intended to empower both the young offender community, on the one hand, to allow their unmediated voice to be heard and the community of the public at large, on the other hand, by allowing them to form their own opinions about the treatment of young offenders based on the direct testimony of offenders themselves, as opposed to information obtained indirectly via the press.

In a sense it was advocating on behalf of young offenders, but rather than advocating in a particular cause, which is what has traditionally been meant by community legal education, it wanted to extend this goal by having the more general aim of seeking to ensure that members of the public had a considered view of the treatment of young offenders. It was a collaboration to create a work of performance art on the part of both the young offenders and the public; the project creating the space for this to occur. It contextualises learning for students by giving them an insight into the issues of social deprivation frequently faced by young offenders and how this might lead to criminality.

It was aiming not only to put teaching and learning in context for students but also put the legal process, insofar as it affects young offenders, into a context for the general public as well.

It was also examining whether use of new technologies can assist the pursuit of social justice and also enhance students' lawyering skills by making them more aware of conditions surrounding actors in the legal process and giving an insight into how the use of new technologies might promote change. 


\section{Using narrative}

There are a number of ways to define narrative, but, at its most abstract, it could be described as a 'representation of an event' or 'a connected sequence of events'.4 Narrative is obviously used in law. It could be said that in civil cases the claimant casts the narrative, the respondent recasts it, and the judge re-recasts it. In criminal cases the jury will process and test the validity of the defendant's narrative in relation to their own narrative as community members. Narrative within law is distilled until one arrives at the ratio decidendi: that combination of law and fact on which the case is decided.

Lord Denning used narrative techniques as a way of conveying, typically with an economical use of words, an impression of the facts of a case. The famous opening line of his judgment in Hinz v. Berry": "It was bluebell time in Kent,"6 conveys in very few words the tranquility and beauty of the scene, immediately interposed to the carnage that was about to occur as a result of a serious car accident. It is a highly evocative statement, and an effective narrative technique.

\section{Using narrative in legal education}

Narrative is being increasingly used in professional education. There are examples of it being used in medicine and accounting and a number of advantages have been

4 Lacy, as cited in Dawn Watkins, 'The Role of Narratives in Legal Education' (2011) 32 Liverpool Law Review 113

[1970] 2 QB 40

ibid 42 
identified in using narrative techniques in legal education. It has been claimed that it leads to greater student engagement by allowing students to create meaning by imagining what happened or could have happened. ${ }^{7}$ It allows for greater empathy and seeing the actors in legal process as fully realised people situated in a social context thereby creating more rounded lawyers.

Students taught in a legal positivist tradition are used to seeing legal education being reduced to a set of rules, to think rationally about these rules, and to privilege rationality over emotion. Narrative though can meet a basic human need. All societies throughout history have used narrative techniques, such as storytelling, so to overlook narrative is to dehumanise legal education. The post modern loss of belief in an objective reality also favours use of narrative techniques. It creates extra dimensions to law students' education as they see the perspectives of others. It creates an alternative to positivistic approaches to legal education and demonstrates to students that there can be an approach to legal education which looks at the law as lived. ${ }^{8}$ Those who have studied use of narrative in legal education have seen its possibility for hearing the voice of those who are suffering and oppressed. It also explores the limits of law and develops an imagination for what the law might become. ${ }^{9}$ Through providing context, it reveals the messiness of many people's lives

$7 \quad$ Michael Blissenden, 'Using storytelling as a teaching model in a law school: The experience in an Australian context' (2007) 41(3) The Law Teacher 260

$8 \quad$ Narnia Bohler-Muller, 'The challenges of teaching law differently: Tales of spiders, sawdust and sedition' (2007) 41(1) The Law Teacher 50, 52.

ibid 
and provides the basis for approaching problems intelligently and creatively for those who go onto to legal advice work.

However, narrative techniques have been criticised for not being clear as to the legal rule in which the problem is grounded, what the legal response should be to problems raised by the narrative or suggesting solutions only in general terms. ${ }^{10}$ Further criticism is levelled at narrative's failure to attempt neutrality and instead aligns itself with a particular group; it also does not test ideas through adversarial debate with those holding opposing views. ${ }^{11}$ Its use of anecdote is unscientific and it is hard to know how far it is possible to generalise from people's specific stories. This latter criticism seems to overlook that narrative is just one of many sources that can be examined when looking at a group's situation. It is not a privileged source but it can be a valued source. There are also concerns that narrative infers your views are less valid if you have not experienced a situation directly yourself. In other words, it creates a danger that it will not be possible to gainsay a young offender's interpretation of their experience of being incarcerated unless you too have been imprisoned as a young offender.

This mistakes the role of narrative. Its role is not to diminish the views of those who have not been imprisoned as young offenders but to more easily empathise with those who have been in that situation and to have a greater insight as to what it might be like to be a youth in prison.

$10 \quad$ Kathryn Abrams, 'Hearing the Call of Stories' (1991) 7 (4) California Law Review 971, 978 11 ibid, 979 
What was experimental about this project was that it attempted to use narrative techniques in community, as opposed to classroom based, legal education utilising new technologies. It aimed to release narratives about the young offenders' experiences of the criminal justice system into the public domain, not to advocate in specific disputes and with no particular end result in mind other than promoting reflections on this experience.

\section{THE TXT INSIDE/TXT OUTSIDE PROJECT}

The project involved two initial workshops working with ten young offenders who were all male and all aged between 15 and 17. They were all held together under secure conditions in the same Young Offender Institution.

In the first two workshops, the texts were produced by the young offenders. In the first workshop the young offenders wrote their responses to a series of prompts:

What is your favourite moment?

What do you think of when you first wake up?

What are your dreams?

What would you like to do when you get out of here?

A group discussion then followed which examined the responses. In the second workshop, three members worked on a one to one basis with the young offenders or in small groups about their experience of the criminal justice system. They were asked if they thought their treatment had been fair; who had helped them when they 
were in trouble; whether they had been listened to during trial and in the Young Offender Institution; and their experiences of being incarcerated.

The characteristics of many of the young offenders reflected those of the prison population as a whole. Members of prison staff told the project team that many had only managed low attainment at school and from the text messages they produced it was clear many had poor self-image. ${ }^{12}$ Whilst there is a strong, systemic emphasis on attaining qualifications in prison education generally in order to enhance the prisoners' prospects in the labour market upon release, there is also an emphasis on developing self-image through experiencing success. ${ }^{13}$ Raising self-esteem is seen by many members of staff working in the system as a necessary precondition to success in education, and one of its major purposes. Art, drama and music are seen as important factors in helping to raise self-esteem. There have been a number of studies which have shown that art as part of a prison education programme raises prisoners' self-esteem. ${ }^{14}$ Art is often a portal through which young offenders pass prior to becoming more engaged in education generally. ${ }^{15}$ Prison officers usually value the acquisition of 'soft skills' for making a contribution to offenders'

12 Jane Hurry and others, Inside Education: The Aspirations and Realities of prison education for under $25 \mathrm{~s}$ in the London area (Sir John Cass's Foundation/Institute of Education, University of London 2012) 4

13 ibid 9

14 L Digard, A von Sponeck, and A Liebling, 'All Together Now: The Therapeutic Potential of a Prison-Based Music Programme' (2007) 170 Prison Service Journal 3; Laya Silber, 'Bars behind Bars: The Impact of Women's Prison Choir on Social Harmony' (2005) 7:2 Music Education Research 251; D Wilson and M Logan, Breaking Down Walls - The Good Vibrations Project in Prison (Centre for Criminal Justice Policy and Research 2005) all cited in K Anderson and Katie Overy, 'Engaging Scottish young offenders in education through music and art' (2010) 3(1) International Journal of Community Music 47, 48 Anderson and Overy (n14) 47 
development; however, the targets set for prison educational programmes in England and Wales focus narrowly on the functional requirements of accredited skills based employment orientated qualifications.

In these workshops some 31 text messages were prepared by the young people (Inside), and 29 of these were cleared by the prison authorities for later transmission; these were 'released' to the public with the public being invited to respond by texting their own messages (Outside). The reasons why two were not approved are discussed below.

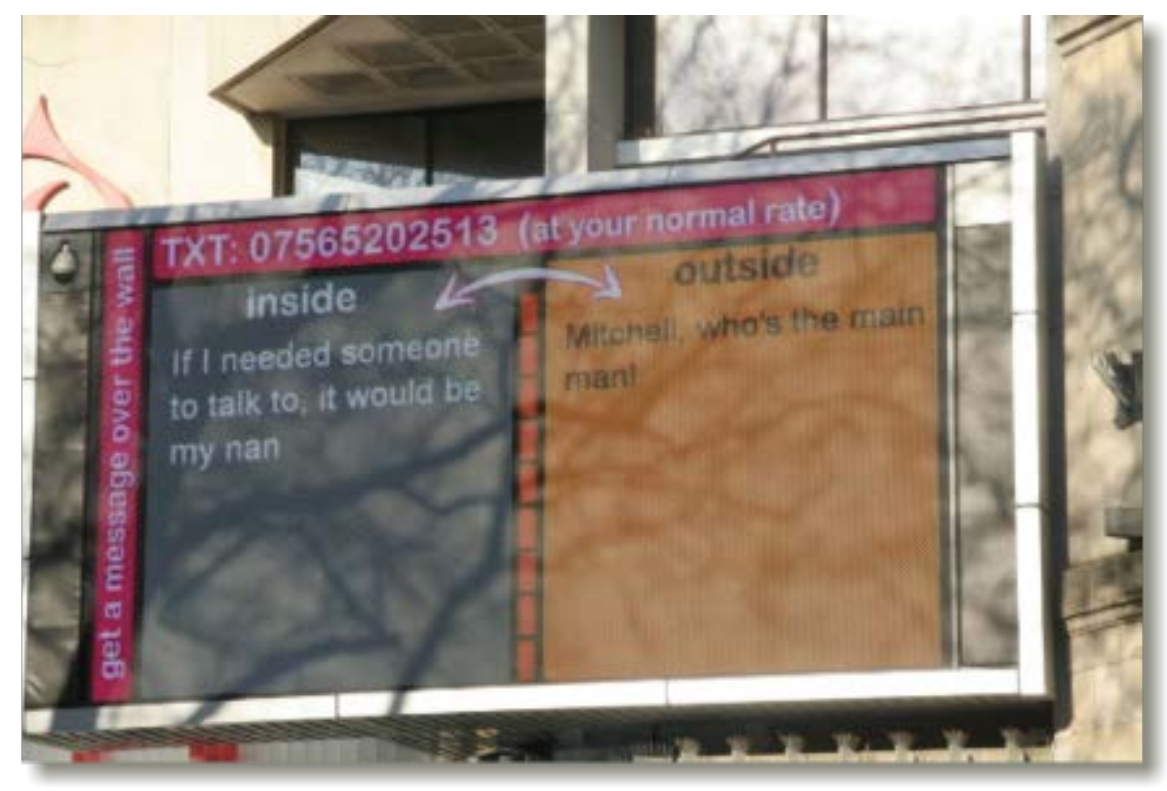

Fig. 1 BBC Cymru Wales Information Screen, Cardiff

On Saturday 11th February 2012, the large BBC Cymru Wales information screen in Cardiff city centre was used to display the messages in a three hour event. Postcards announcing the event and inviting participation were handed out by the team in the morning. The messages of the young people in custody were displayed on the left 
hand side of the screen, while the passing public sent live SMS text messages for instant display on the right hand side. A live roll of adjacent text messages from the young offenders and the public was created putting them in 'dialogue' with one another.

The event was videotaped and included interviews from members of the public. An edited documentary was played two weeks later to the young offenders in a final workshop. The film provided a platform for discussion of the original text messages written by the young people, of the messages posted on the screen by the public, and of the interviews with members of the public. The young people in custody who saw their messages displayed on the large, public screen in the film appeared to be profoundly moved. Their behaviour was noticeably different from the two earlier workshops when they had been more exuberant, and more inclined to allow their attention to wander. Experienced prison officers who were present at the screening commented on unprecedented levels of attention and focus.

The decision to use texting was intended to be a reflection of teenagers' lives today. Whilst people of all ages are increasingly reliant on mobile phones to transact all manner of business, teenagers are particularly dependent on mobile phone technology to conduct a social life. 
Adolescents have been shown to be heavy users of all forms of electronic communication, including text messaging. ${ }^{16}$ Virgin Mobile USA reports that two thirds of teenagers with mobile phones send text messages daily; half of Virgin's customers aged between fifteen and twenty receive at least eleven text messages a day, while approximately a fifth text twenty one times a day or more. ${ }^{17}$ Electronic communications have the effect of reinforcing the relationships of adolescents with their peers at the expense of communication with their parents; it expands their social circle; enables them to join offline cliques; plan social events; and it is often a vehicle to form and maintain romantic attachments. Electronic communications such as instant messaging and texting have been found particularly useful by adolescents as a way of talking freely to members of the opposite gender. ${ }^{18}$ However, use of electronic communications is not wholly positive. The more private forms of electronic communication, such as texting, have been found in reports of usage in the United Kingdom to have particularly high levels of harassment and bullying. ${ }^{19}$ Undoubtedly, loss of the phones and the resulting ability to text means that offenders lose many avenues of communication, which weakens their sense of identity. Creative activities involving texting help them rediscover their voice and emphasise the more positive uses of texting. 
Best practice in prison education also shows that the positive results are more likely to be obtained when a project draws upon prisoners' age related interests and culture so text art is seen as a suitable vehicle for engaging young offenders. ${ }^{20}$

1. Methodology for evaluating the project

A recursive approach was taken to methodology in which outcomes were continuously reviewed and assessed; the lessons were learnt and reinvested in the next stage of the project.

As the project was predicated on the basis of the responsivity of not only offenders but also members of the public, it had to adapt to the offenders' reports of their experiences and priorities and the public's reaction to them. As a result, observation was thought to be the best way of gaining insight into the effect of the process on the offenders and as a form of community legal education.

An observation framework was developed with project team reflections after each stage of the process also sometimes involving prison officers for the stages held in the prison. This involved the project team meeting immediately after each session and assessing the young offenders' engagement with the process. The framework looked for the young offenders' attitude to their trials whether they regarded the process as fair; their attitude to the actors in the legal process; who they regarded as 
supportive and who was unsupportive; their life experiences, particularly risky behaviours, and whether they made any link between them and offending; their experience of prison life; and their ambitions for the future.

These areas were being observed to see if they felt that their trials had followed due process; whether or not they regarded their legal representatives as being effective; who could be of assistance in preventing reoffending and who and what might cause them to reoffend; whether they regarded their treatment in prison as capable of rehabilitating them; and whether or not they regarded their prospects as blighted as a result of imprisonment.

After the first session, the project team had to assess how to deal with the young offenders' attitude: they were convinced that the project was designed to exploit them and make money out of them in some way. They were impressed by the expensive equipment which had been taken into the prison, but this further convinced them it was a money making venture.

As a result of the lack of trust shown by the young offenders towards members of the project team during the first session, there was much more one to one interaction between members of the project team and the young offenders during the second session. The reflection on the first session also concluded that the overall feeling amongst the young offenders was that they had been fairly treated by the criminal justice system and they were many who believed in due process even if they did not express it in that way. The team reflected on how far it was possible to probe. In the 
event, the greater incidence of one to one interaction in the second session made it easier, as it was more conversational and it was possible to ask for elaborations on statements or gently challenge what had been said.

Prison officers and educators had been present at the third session where the film was screened. Everyone discussed their observations of the young offenders: how attentive they had been, and their emotional reaction. Everyone involved put forwarded their explanations for their reactions.

Ten young offenders completed a Sense of Coherence questionnaire at the start of the first workshop and another ten the end of the final workshop although of the final ten only six were from the initial group. The inevitable churn in the prison population meant that some of the original group were no longer being detained in the Young Offender Institution whilst new inmates made up the rest of the group for the final session. This is a small group and it is hard to see with a declining population in Young Offender Institutions how it could be anything other. Equally, it is difficult to see how it would be possible to stick with the same group of young offenders through the project. In addition to young offenders completing their sentences they may be unavailable due to other reasons.

Sense of Coherence is the inclination to assess life events as "comprehensible": events are perceived as ordered, consistent, structured; "manageable": whether you feel you can cope with events; and "meaningful": the extent to which life makes sense and it is worth making, as a result, a commitment to things. In other words, it 
is the ability to cope with and assess events in order to behave in a constructive way. The concept of Sense of Coherence was first put forward by Aaron Antonovsky in 1979 to explain why some people respond better to stress than others. It arose from the salutogenic approach i.e. the search for the origins of health rather than the causes of disease.

Permission was sought and obtained to use a questionnaire which had been adapted for children's needs and uses a 19 point scale. ${ }^{21}$ However, some suggestions were made to alter it for adolescents. The more childish references which were consequently thought to be inappropriate referred to ice cream and school classes. Examples of questions used included:

When I need help, there is someone around to help me.

$\begin{array}{cccc}1 & 2 & 3 & 4 \\ \text { never } & \text { sometimes } & \text { often } & \text { always }\end{array}$

I feel that I'm not being treated fairly.

$\begin{array}{cccc}1 & 2 & 3 & 4 \\ \text { never } & \text { sometimes } & \text { often } & \text { always }\end{array}$

I feel confused, mixed up.

$\begin{array}{cccc}1 & 2 & 3 & 4 \\ \text { never } & \text { sometimes } & \text { often } & \text { always }\end{array}$

$21 \quad$ Permission was kindly given by Professor Malka Margalit of Tel Aviv University to use a questionnaire he had devised and used for children although he suggested amendments as the project was working with adolescents. 
The questionnaire was designed to measure the offenders' feelings of control, optimism and self-esteem at the beginning and the end of the project. Previous research with young offenders in Spain found they had moderate Sense of Coherence scores. ${ }^{22}$ The research took the health assets model which is defined as factors and resources which enhance the ability of an individual, group, community or institution to maintain health and wellbeing and reduce health inequities.

The young offenders in the Spanish research did not mention self-esteem or positive role models as assets in the promotion of health. ${ }^{23}$ They also did not regard relating to any community group or association to be an asset even though other research has shown it has positive health benefits. ${ }^{24}$

2. Issues around young offenders held under secure conditions

Whilst the types of issues young offenders would raise could not be predicted in advance, the public debate around young offenders in England and Wales has been informed by a number of issues which have caused widespread concern.

The most broad offence types are breach (breach of statutory order, bail or conditional discharge) committed by $21 \%$ of children committed to custody; violence against the person committed by $20 \%$; robbery committed by $17 \%$; and burglary

22 JJ Paredes-Carbonell and others, 'Sense of coherence and health assets in a youth center for minors' (2013) 15 Rev Esp Sanid Penit 87

$23 \quad$ Ibid 95

24 ibid 
committed by $13 \% .^{25}$ The young offenders who participated in the project reflected the typical young offender population when it can to offences of violence, robbery and burglary but none had committed breach offences. The rest were made up of offences relating to drugs.

The numbers of young people held under secure conditions in England and Wales although historically high has been in sharp decline since 2008. However, although the numbers of young offenders held in secure conditions are in decline, the number of offenders from ethnic minorities is rising: 39\% of those held, which is up from $33 \%$ in $2009 / 10 .{ }^{26}$ The percentage of ethnic minority offenders involved in the project at $30 \%$ was lower than the percentage for the entire population of young offenders in England and Wales.

In addition, young offenders from ethnic minorities are more likely to have a less positive experience of being held in secure conditions than their white counterparts: there has been a 'steady decline' in those who thought the majority of staff treated them with respect with the perception of black and ethnic minority young people worse than that of whites. ${ }^{27}$ This was reflected in the young offenders who participated in the project. They were less happy with the way they had been dealt with by the criminal justice system and the treatment they were receiving in prison.

25 Jessica Jacobson and others, Punishing Disadvantage: a profile of children in custody (Prison Reform Trust 2010) 14

26 Amy Summerfield, Children and Young People in Custody 2010-11. An analysis of the experiences of 15-18-year-olds in prison. (H.M. Inspectorate of Prisons/Youth Justice Board 2011) 7

27 HM Inspectorate of Prisons, HM Chief Inspector of Prisons for England and Wales Annual Report 2011-12 (The Stationary Office 2012) 75 
There is a problem of bullying in Young Offender Institutions. It is estimated that $25 \%$ of young men in prison have been victimised by others. ${ }^{28}$ Victimisation covers a range of behaviour from name calling to murder, as in the case of Zahid Mubarek who was murdered in Feltham Young Offender Institution by his racist, psychopathic cellmate in 2000. The most common type of victimisation is being hit, kicked or assaulted which is reported in $11 \%$ of cases. ${ }^{29}$ Twenty-two per cent of inmates report being victimised by staff with insulting remarks at $12 \%$ being the most commonly reported form of victimisation. ${ }^{30}$ Unsurprisingly, it was hard to get the young offenders to talk about bullying probably because of the public nature of the discussions.

Incarceration can often be predicted from the socio-economic circumstances which prevailed at birth, with a quarter of male young offenders having been in care. ${ }^{31}$ Troubled or disrupted family life is another feature of children in trouble with the law. A study of children and young people in custody and the community found that two thirds came from families where the structure has broken down and only one third come from families where the biological parents remain married or living together. ${ }^{32}$ The participants reflected these statistics. About $9 \%$ of children in

$28 \quad$ ibid

29 Ewan Kennedy, Children and Young People in Custody 2012-13 An analysis of the experiences of 15-18-year-olds in prison (HM Inspectorate of Prisons/ Youth Justice Board 2013) 39 ibid $40-41$ HM Inspectorate of Prisons and Youth Justice Board, Children and Young People in Custody 2010-11. An analysis of the experiences of 15-18-year-olds in prison. (The Stationary Office 2011) 7

32 Richard Harrington and Sue Bailey, Mental Health Needs and Effectiveness of Provision for Young Offenders in Custody and Community. (Youth Justice Board 2005) 38 
custody are parents themselves. ${ }^{33}$ Using small numbers, the participants reflected this as one $(10 \%)$ already had a child with a partner expecting another child. For many young offenders crime is a family business: around one third have a parent or sibling who is involved in criminal activity. ${ }^{34}$ The project team found through discussion that at least two of the participants had siblings who were in trouble with the law. Another study of children who are persistent offenders also found higher than average levels of loss, bereavement, abuse and violence experienced within the family. ${ }^{35}$ One participant had suffered the loss of a sibling. In addition, children in custody often suffer multiple layers of disadvantage experiencing not only problems within the home and family but also psycho-social and educational problems as well. From observing the participants and information provided by prison officers, it would seem that they reflected this too.

Holding young people under secure conditions is not proven to be effective. Seventy three per cent of offenders held within Young Offender Institutions reoffend with a high likelihood that they will reoffend within a year. ${ }^{36}$ The participants did not see any rehabilitative benefits to being incarcerated and there was a broad consensus that they would be forever stigmatised after being imprisoned.

3. Young offenders do not always see themselves as victims

$33 \quad$ ibid 53

34 ibid

$35 \quad$ Elaine Arnull and others, Accommodation needs and experiences (Youth Justice Board 2007)

36 Ministry of Justice, Transforming Youth Custody Putting education at the heart of detention (Stationery Office 2013) 8 
Whilst the issues such as multiple disadvantages are of widespread concern in academic circles, they are not always reflected in the views of young offenders themselves. Amongst the text messages put forward by the young offenders were the following:

- Do the crime do the time

- My solicitor helped me most when I was in trouble

- My family and my solicitor helped me most when I got in trouble

Many of them seemed to have faith in the due process of the criminal justice system. In discussions, there was broad, but not unanimous, agreement that they would not be in prison unless they had done something wrong. They only said complimentary things about their solicitors, and clearly thought that they had been well represented. This, of course, might have been due to concern that the project team or others might pass on negative comments to the prison authorities.

Of those who commented, they regarded their families as effective support mechanisms. The grandmother was frequently cited as an important figure who held the family together often in what must be difficult circumstances.

These comments show a belief in the criminal justice system, that the young offenders felt they had been effectively represented and supported by their families. However, academics often believe that there are serious deficiencies in the youth justice system and that crime is often a result of socio-economic and personal 
circumstances. ${ }^{37}$ This creates an ethical dilemma that a well-educated, liberal elite, might well see young offenders as victims of circumstance projecting their ideas onto these young offenders who do not self-identify as victims.

4. Evidence that young offenders do see themselves as excluded

There were other messages which were more critical of the criminal justice system.

One example is the following:

- I don't think the judge understood my life - the things that are important to me

This would appear to be an argument in favour of using narrative techniques in community legal education. The feeling amongst young offenders that their lives differ from decision makers and that their voice is not heard was picked up in other texts:

- You'll only listen to a millionaire

- I really doubt anyone would listen to a young offender

Fifty one per cent of children in custody come from deprived households which is defined as households on benefits or where there is unsuitable accommodation compared to $13 \%$ in the population as a whole; $39 \%$ have experienced abuse in the family compared to $16 \%$; $7 \%$ have parents with substance misuse problems compared to $2-3 \%$; and $12 \%$ have suffered bereavement through loss of a parent and/or sibling compared to $4 \%$. Source: Jacobson (n 25) 52 
There was a strong feeling that as they had been convicted, they were now locked into a lifetime of stigmatisation as a result of their conviction and would never escape its effects:

- Shit sticks for life

- As soon as you've been in once the police will come knocking on my door

Further mistrust of the police, and less confidence in the criminal justice system, was demonstrated by this statement:

- I really don't trust the police at all

The $21 \%$ of young offenders held in care and separation units was referred to obliquely in this statement: ${ }^{38}$

- He can't ride his bang up

This was a reference by the young offenders to one of their number who was physically restless after having been held apart from the rest of the group, as a punishment, in a care and separation unit and was finding it difficult to settle back within the group after coming out of the unit.

In most, but not all cases, there was a sense that their life chances were severely diminished, that they were disengaged from education, and their prospects were pretty hopeless, as shown by this statement: 
- Most YPs [Young Prisoners] don't come to education to learn, they come to associate with others

It is hard to tell whether this is a reflection of the young offenders' view of their future, i.e. it is destined to be bleak, or whether it is a reflection of their view of the relevance of the curriculum they were studying. This would explain why their Sense of Coherence scores were low.

One young offender did, however, express great optimism about his prospects on release. He played sport at an elite level which has probably contributed to a greater Sense of Coherence in his life as his life is imbued with greater meaningfulness and is in line with the Spanish research. ${ }^{39}$

Clements (2004) draws on literature to draw a distinction between 'education of empowerment', on the one hand, which is defined as personally transformative education and distinguishes it from 'education of emancipation', on the other, which is aimed at critiquing the system's structures and transcends individual concerns. ${ }^{40}$ The young offenders are challenging the power structures in the community and the nation. They are proclaiming their social exclusion; that they lack a voice; and that they are stigmatised for life which is an injustice as the effects of the punishment vastly exceed the prescribed period of punishment. They challenge existing structures in an 'education of emancipation' whilst 'education of

40 Paul Clements, 'The Rehabilitative Role of Arts Education in Prison: Accommodation or Enlightenment' (2004) 23(2) Journal of Art Design Education 169, 174 
empowerment' would be directed at individual transformation. ${ }^{41}$ However, there are limits to these emancipatory aspects, as some messages supported the structures of the criminal justice process, and none really challenged their socio-economic status despite the link between this and incarceration or the less positive experiences of black and ethnic minority young offenders in prison. Also absent was any challenge to the need to detain them in penal institutions despite the fact that England and Wales has, on an historic, comparative basis with other European countries, felt the need to detain so many young people. ${ }^{42}$

\section{Unused messages}

The prison authorities would not allow use of two of the text messages. One was refused as it was thought to glorify crime. The text had been, 'Valleys' boys on tour', which was a reference to the offenders coming from the South Wales valleys. The other was refused as it commemorated the tragic early death of the brother of one of the young offenders, and therefore was capable of identifying him. The project team asked the prison authorities to speak to the young offender concerned to explain the situation. He attended the third and final session and challenged the team as to why

$41 \quad$ ibid

42 On $1^{\text {st }}$ September 2006 there were 2,751 teenagers in custody in the UK compared to 646 in France and 1,422 in Germany. Note that the figures are given for the UK even though youth justice is a devolved issue for Scotland and Northern Ireland. Source: BBC News, 'Too many' young offenders jailed' (13 August 2009) < http://news.bbc.co.uk/1/hi/uk/8198496.stm\#map> accessed 27 June 2014 
the text had not been used, and the situation was explained again. Whilst his demeanour was inscrutable, it is reasonable to assume that he was disappointed.

The prison authorities also objected to a comment by the interviewer in the film which referred to the number of hours young offenders spend out of their cell each day. The figure was based on information supplied by a young offender to the interviewer, but the authorities insisted it was not accurate. Whilst it is possible the figure was not accurate, the amount of (or lack of) young offenders' out of cell time would surprise many. Figures vary depending on the type of regime a young offender is on such as the level of rewards, etc. However, sixteen hours a day confined to a cell by a young offender who is not being punished is still seen by the Chief Inspector of Prisons as being consistent with a well-run Young Offender Institution. ${ }^{43}$

The comment by the interviewer in the film shows the limits of narrative techniques. There is an issue to explore over the lack of time young offenders, who are young people with a lot of energy to burn, spend outside their cells. However, because the figure provided was contested and may not have been accurate then discussion was pre-empted even though the issue was valid. It creates ethical dilemmas. The project team wanted to empower the young offenders by giving them a voice. The first two workshops encouraged them to think that their voice would be heard without being censored, yet inevitably comments have to be approved by the prison 
authorities before being broadcast otherwise permission would never have been given to work with them in the first place. Any such projects have to make it clear, at every stage, to the young offenders that there is not complete freedom to broadcast their views and that comments have to be approved by prison authorities before being released to the public.

6. The 'stage event'

When the texts were shown at the stage event there was minimal mediation of the public's responses. Texts were received in a control room where one of the project team was based and there was a slight delay before they were shown on the screen. Any texts submitted by members of the public which breached any of the participating institutions' equalities policies would not have been displayed. In the event, there were no such comments.

Whilst the stage event was taking place, an interviewer was circulating with a film crew asking onlookers questions and going through the texts, printed on card, with the interviewees asking for their reaction. All onlookers who were asked to give an interview agreed.

When asked whether they would employ a young offender a number of people answered that it depended on the offence. Crimes of violence were cited more than once as a reason for not employing a young offender. When one interviewee was 
asked whether she would give a job to a young offender she said, 'It depends on what he's done, I suppose, isn't it?' When asked by the interviewer when she would not give a job to a young offender, she said, 'Violent crime, things like that. You would want to know they are properly reformed rather than taking them on but if it's petty crime there's probably a reason behind it.'

Statistically, one fifth of young offenders will have committed acts of violence. ${ }^{44}$ Some of the offenders who participated in the project had been convicted of serious offences of violence, and would therefore be regarded by many members of the public as unemployable. It is submitted, that although such offences can have serious effects, from discussion with the participants their accounts of their own acts of violence seemed to be the result of teenage impetuosity or poor judgment. It seems unjust that a young offender could suffer for their offence through being unemployable for the rest of their life when they may have genuinely been rehabilitated. A violent offence committed whilst an adolescent is not necessarily an indicator that the person will have a propensity towards violence throughout life; it only proves that they are violent at the time of the offence. It also overlooks the complexity of problems which contribute to youth crime. Many offences are linked to alcohol and/or substance abuse. If the underlying problem relating to abuse is resolved then the propensity to violence may disappear. They are more likely to 
have suffered abuse and bereavement. Again propensities towards violence may decrease if they receive suitable treatment.

There was, however, awareness amongst at least some members of the public that young offenders will have suffered deprivation prior to imprisonment. It tended to be expressed as genuine sympathy for young people who had lived difficult lives. This was the attitude of virtually every interviewee whilst the stage event was taking place.

This type of event does have the potential to move forward public debate by getting the public to think through their attitudes towards rehabilitation of young offenders. Previous studies have shown that 'face-ing' young offenders, i.e. having information about a young offender, means that the public are more like to rate them favourably. ${ }^{45}$ Previous trials have shown that members of the public are significantly less punitive when given extra background information about a young offender than those given basic information. ${ }^{46}$ The public were generally sympathetic to the young offenders possibly because of the fact that they had discovered more about them. Of the twelve people interviewed, all expressed some degree of sympathy for the young offenders.

As the whole idea was that the conversation could not be controlled some messages, inevitably, were frivolous:

$45 \quad$ KN Varma, 'Face-ing the Offender: Examining Public Attitudes Towards Young Offenders' (2006) 9(2) Contemporary Justice Review 175

$46 \quad$ Varma (n 47) 178 
Young Offender: My favourite moment when my ex Mrs gave birth to my baby. Now my girlfriend's pregnant.

Texted reply: Get drunk and smoke

In answer to the same message an interviewee said, 'That's sad isn't it? They can't be there for the baby's first months or days.'

There was also some cynicism expressed about the process:

Young Offender : $S^{* * *}$ sticks for life (This was the from it appeared on the screen).

Texted reply: How much censoring are you doing b00110ks

Although there was less so from interviewees, 'I suppose that's true, isn't it? Everyone makes mistakes. You know what I mean?' Although a less sympathetic tone was adopted by another interviewee who said, 'I suppose prison stops some people doing it again, but some people just live off it.'

The public did show awareness of the lifelong effects of stigmatisation as shown by these exchanges:

Young Offender: As soon as you've been in once the police will come knocking on my door.

Texted reply: Are we free?

In answer to the same message an interviewee said, 'I think it almost becomes like a vicious circle when you're a young offender. There's always the fear of being picked up for something again. It stops you living a proper life really, in the way you should do. If I 
interpret this right, the person probably has redeemed themselves but can never quite free themselves from their past and it's quite sad.'

Another interviewee was prepared to criticise the criminal justice system with its historic tendency to incarcerate large numbers of young offenders in England and Wales, 'It shows you need to reform how you're doing it and why you're doing it. Whether that's lessening what you are locking people up for or having, you know, a work study programme or community service instead ...because locking impressionable young people up with tons of other offenders, it just means they are more likely to commit another crime.'

There were signs of a connection being made. In response to a text which said, 'All I look forward to in my regular day is going to bed,' one interviewee said, 'That's when I felt suddenly, you know, some of those small things we start taking for granted until you look at it from the people who are in those kind of circumstances, we feel how important those things are. What I was saying is that for kids, say ten or twelve years old, if they realised this it would change their thought processes, their behaviours for good. I think the impact it has is something you cannot explain. You know, you can feel it here. The feeling has come from [the young offenders] directly.'

Members of the public were prepared to engage in repartee or possibly a sideswipe, as is shown by this:

Young Offender: When I got in trouble, I didn't help myself

Texted reply: Helping myself got me in trouble 
Another did not seem to think life was wonderful on the outside or perhaps it was though necessary to console the young offenders:

Young Offender: I would most like to become a plumber and have a steady job Texted reply: We're free to buy things. Look how happy we are! :)

7. The final workshop

The documentary film that was made of the stage event was shown to the young offenders. The atmosphere of this final workshop was very different from the first two when the text messages were being prepared. Whilst they had initially been exuberant, but probably no more so than adolescents of an equivalent age at secondary school, in the final workshop they paid rapt attention. This included young offenders who had been brain damaged through glue sniffing who find maintaining concentration over a prolonged period difficult. The prison officers who were present commented that they had never previously seen such sustained concentration from them.

Their reaction was initially curious. Early in the film three women appear who were a grandmother, mother and daughter from the same family. The grandmother is interviewed and is highly sympathetic to the young offenders. One of them shouted out 'bitch' which was particularly surprising as grandmothers were widely identified 
as a supportive figure in the earlier workshops. Shortly following this outburst one of the young offenders burst into tears, and was followed by others.

There are a number of possible explanations for this reaction. As already noted, young offenders frequently suffer from low self-esteem and often do not feel that they are listened to. This is borne out by the text messages they prepared. It could be that a public event where random members of the public treat their comments with great seriousness was an unprecedented and overpowering event in their lives.

Secondly, a Young Offender Institution is a dangerous place for an adolescent. One quarter of young offenders complain of having been victimised in prison. ${ }^{47}$ This could well lead to the need to adopt an invulnerable, 'hard man' persona to their fellow offenders to deter any attempts at victimisation. This could be an 'external' self which bears a weak relationship to the prisoner's interior life or their 'internal' self, which may be tormented by homesickness, anxiety, and any other number of vulnerabilities. It is possible that the effect of the film was to break down the wall between the external and internal self so that they were able to present a more authentic face to the world. Such an emotional reaction shows that the group communally underwent a 'felt' experience, which suggests that it was particularly meaningful for them. ${ }^{48}$ This greater authenticity in their emotional displays has the potential to increase trust within the group. It could help with the manageability of their emotions so develop their Sense of Coherence, which, in turn, could lower 
reoffending rates. The second Sense of Coherence questionnaire showed 20\% higher scores and, therefore a better sense of coherence, on questions such as 'I feel confused, mixed up', but as the sample was small and it was beyond the power of the project team to control the group.

The strength of the emotional reaction took the project team by surprise. This meant that there was an insufficient framework to deal with it. It is hard to discuss this publically with young offenders when it is known that they are living in an environment rife with bullying and harassment. It would be better to have had breakout sessions where the young offenders have the opportunity to discuss their feelings privately.

\section{CONCLUSIONS}

The project was experimental in nature and the 'stage event' took place on one day in one city so there are limitations on the extent to which it is possible to generalise about the project. However, it does show that this type of interdisciplinary work does have the potential to engage in meaningful community legal education.

Use of narrative is sometimes criticised for not being clear as to the type of legal response that is required in answer to a particular problem. Yet it was clear from the young offenders' accounts that they suffer a lifelong blighting of employment prospects, which is a well-defined problem. Whilst the solution is less clear, it is 
clear that rehabilitation is the area that needs to be on the agenda. It can therefore be a useful part of a student's clinical legal education as they can work on specific solutions where a general area for concern has been identified and it places their learning and teaching in context.

It offers the possibility of enabling students to reflect critically on the structure of the criminal justice system by witnessing its effects firsthand, and getting them to think of solutions to problems such as lifelong blighting of opportunities as a result of imprisonment. Such 'education of emancipation' will complement other approaches on their programmes.

It creates the possibility of assisting in the rehabilitation of young offenders. The Sense of Coherence questionnaires, the observations of the prison officers at the third workshop and the emotional reaction of the young offenders all point to the project having enhanced the young offenders' self-esteem. The seriousness with which their views were taken could be significant in building self image and reconstructing their identity which is seen as a necessary precondition to them succeeding in educational activities.

It can help improve the young offenders' self-awareness as they are afforded greater insight into how they are perceived by the public at large. This can help them connect, as the Spanish Sense of Coherence research shows that young offenders 
typically have a weak connection to community. ${ }^{49}$ They can be reassured that attitudes towards them are sympathetic albeit conditional.

The lessons they can learn from the reaction to their narrative could help them overcome the stigma they face and which parts of the narrative they need to reveal to overcome prejudice. For example, as there is a particular prejudice against young offenders who have committed acts of violence, they need to be aware that people need to know the underlying causes such as drink or alcohol related offences or impetuosity and demonstrate that these underlying causes have been successfully addressed. In this way, use of narrative helps reconnect them with society and breaks down their isolation.

Undergraduate law students, have the potential to add a lot of value to a project of this nature in excess of academic staff. Young offenders in prison education have a particularly strong need to identify with their educators, to see them as role models with a shared understanding of their culture. ${ }^{50}$

There are a number of difficulties which remain to be overcome. Any art course as part of a prison education programme has to fight for survival. This puts a premium on demonstrating measurable improvements in projects of this nature, and having the research skills to be able to do this. The project did experience difficulties in measuring the offenders' increases in their self-esteem. Sense of Coherence 
questionnaires were distributed and completed at the beginning and end of the project but there was a lot of churn in the offenders involved in the project in its various stages. Offenders were not always available because they had meetings with probation officers or social workers, had been placed in a Care and Separation Unit, or were released. Some of the offenders who completed questionnaires at the end had not completed them in the beginning making measurement in the change of Sense of Coherence challenging. In future, the project needs better coordination with prison officers, and the project team needs to explain to them the reason behind the Sense of Coherence questionnaire and work with them to ensure there is a viable control group. Churn is inevitable in a secure environment, and will always occur, but that should not prevent the formation of a viable control group.

Clinical legal education students will need an ethical awareness of issues relating to this type of project. There is always the possibility of imposing a 'privileged' voice in respect of offenders who do not see themselves as victims at all. This creates a dilemma as to the extent to which they should prompt or challenge young offenders when they do not discuss issues such as their socio economic status; institutional racism; victimisation within prisons or recidivism rates when there is evidence to suggest that these are problems. Do you probe young offenders when they say they are satisfied with the standard of their legal representation? At what point does it cease to be the offenders' own authentic voice if you do? 
Another ethical consideration is the need to be aware of managing the young offenders' expectations, for example, the text message which was a memorial to the dead brother of a young offender and which was not released by the prison authorities. It is best to stress throughout the process that not all messages are able to be used even if they are of great personal significance.

The main benefit for clinical legal students is that they experience more perspectives on the criminal justice process than could be gleaned from other educational approaches. Their exposure to young offenders' narrative gives them a deeper understanding of those at the centre of the process. 